\title{
Ingestive behavior, performance and forage intake by beef heifers on tropical pasture systems
}

\author{
Renato Alves de Oliveira Neto', José Henrique Souza da Silva², Marta Gomes da Rocha1, \\ Luciana Pötter ${ }^{2}$, Maria José de Oliveira Sichonany ${ }^{1}$, Ludmila Leonardi Biscaíno¹, Felipe \\ Asconavieta dos Santos ${ }^{3}$, Marcos Vinicios Beck Difante ${ }^{3}$
}

\author{
${ }^{1}$ Post-graduate Program in Animal Science, Universidade Federal de Santa Maria (UFSM). \\ 2 Universidade Federal de Santa Maria. \\ ${ }^{3}$ Undergraduate Course of Animal Science (UFSM).
}

\begin{abstract}
The experiment was carried out to evaluate forage intake, performance and ingestive behavior of beef heifers. Productive, structural and chemical characteristics of the pasture were also evaluated. The experimental design was completely randomized in a $3 \times 2$ factorial arrangement, with three pasture systems (Alexandergrass [Urochloa plantaginea Link.] with and without supplement to heifers and Coastcross [Cynodon dactylon (L.) Pers.]) and two phenological stages: vegetative and flowering. The grazing method was put-and-take stocking. Grazing, ruminating and idle activities, feeding stations, displacement patterns, bite mass and bite rate were evaluated. The forage intake was estimated using chromic oxide as an indicator of fecal output. The heifers modified the use of feeding stations and displacement patterns between phenological stages and pasture systems. Heifers consumed more forage in the vegetative stage $(2.81 \%$ of body weight in dry matter) than in the flowering stage (1.92\% of body weight in dry matter). Average daily gain, body condition and stocking rate were similar for heifers in the evaluated systems. Beef heifers receiving protein supplement on Alexandergrass pasture consumed more forage than heifers fed Coastcross exclusively. Regardless of the species, no difference was observed when the heifers were exclusively on pasture. Pasture systems on Alexandergrass or Coastcross provide suitable nutrient intake for heifers to be mated at 18 months of age.
\end{abstract}

Key Words: chromic oxide, Cynodon dactylon, feeding station, Urochloa plantaginea

\section{Introduction}

The inclusion of warm-season grasses as summer pastures for beef heifers to be mated at 18 months of age is necessary to make the feeding system viable, providing nutritional support to these animals. Among these forages, despite being considered a weed, Alexandergrass (Urochloa plantaginea Link.) has high potential as a pasture, similar to millet and sorghum (Restle, 2002), while the Coastcross (Cynodon dactylon (L.) Pers.) is a species with high dry matter production and allows over seeding with temperate species such as oats and Italian ryegrass (Rocha et al., 2007). In feeding systems, where the objective is rearing heifers, both forage species allow them to reach an adequate body weight and body condition score to successfully reproduce at 18 months of age (Costa, 2009).

The performance of grazing animals is indicative of forage quality (Moore, 1994) and given that the advancement in phenological cycle of forage species usually results in increased levels of fiber and low protein content, the animal productive response is impaired due to these factors that limit forage intake (Van Soest, 1994).
In this case, on animals consuming low-quality forage, the usage of protein supplement may assume importance through the effects of this kind of supplement that are associated with better efficiency of rumen fermentation, a higher ruminal degradation rate of fiber and forage intake (Mathis et al., 2000).

The evaluation of ingestive behavior components on animals dealing with different pasture structural characteristics and phenological grass stages makes it possible to identify the way animals are exploring the grazing environment (Prache \& Peyraud, 2001). The estimate of forage intake may be crucial to explain longterm factors that interact in the plant-animal relationship and determine ruminant performance.

Methods that use external markers such as chromium oxide can produce data with some precision (Le Du \& Penning, 1982). The behavioral changes may determine the ingestion level, since the rules of choice and avoidance of feeding stations affect forage intake and efficiency of grazing process (Moraes \& Carvalho, 2005). The objective of this study was to evaluate performance and forage intake by beef heifers on Coastcross and Alexandergrass 
pastures receiving protein supplement or not receiving it, and to establish a relationship for behavioral parameters of animals and chemical and structural characteristics in vegetative and flowering phenological stages.

\section{Material and Methods}

The experiment was carried out from December 2009 to April 2010, at Universidade Federal de Santa Maria. The climate in the region is humid subtropical; a $\mathrm{Cfa}$ type, according to the Köppen classification. The soil is classified as Paleudalf (Embrapa, 2006). The mean values for chemical characteristics of the soil in the experimental area are: $\mathrm{pH}_{2} \mathrm{H}_{2} 0: 5.0$; $\mathrm{pH}-\mathrm{SMP}: 5.8 ; \%$ clay: $19.2 \mathrm{~m} / \mathrm{V}$; P: $13.4 \mathrm{mg} / \mathrm{L} ; \mathrm{K}: 92 \mathrm{mg} / \mathrm{L} ; \%$ organic matter: $2.7 \mathrm{~m} / \mathrm{V} ; \mathrm{Al}^{3+}$ : $0.2 \mathrm{cmolc} / \mathrm{L} ; \mathrm{Ca}^{2+}: 4.6 \mathrm{cmolc} / \mathrm{L} ; \mathrm{Mg}^{2+}: 2.2 \mathrm{cmol} / \mathrm{L} ;$ base saturation: $56.6 \%$; $\mathrm{Al}$ saturation: $3 \%$.

The field was divided into six paddocks (experimental units) of 0.8 ha, plus a reserved area of 1.5 ha for the putand-take animals when they were not necessary for forage mass adjustment. Coastcross (Cynodon dactylon (L.) Pers) had been established since May 2006. Alexandergrass (Urochloa plantaginea Link.) was established by a sub soiling and two diskings on December 10th. Paddocks received $250 \mathrm{~kg} / \mathrm{ha}$ of fertilizer $05-20-20$ (N:P:K) and $45 \mathrm{~kg}$ of nitrogen $(\mathrm{N}) / \mathrm{ha}$ in urea form, subdivided in two applications on January 11th and February 10th.

The ingestive behavior and performance of Angus heifers, with initial age and body weight of 15 months and $253.3 \pm 4.8 \mathrm{~kg}$, respectively, were evaluated. Heifers were kept exclusively on Coastcross, Alexandergrass or in Alexandergrass plus $0.2 \%$ of body weight (BW) in protein supplement. In two occasions (February 3rd-14th and March 17th-28th), corresponding to vegetative and flowering phenological stages of Alexandergrass, respectively, the forage intake was evaluated.

The grazing method was put-and-take stocking, with four test animals per paddock. Among these, two were orally dosed with chromium oxide for determination of fecal output.

Heifers were daily supplemented at $08 \mathrm{~h} 00$ with a commercial product $(34.0 \%$ crude protein) consisting of soybean meal, whole soybean meal (roasted grain), vegetable oil, urea and minerals. To determine the supplement intake ( $\%$ of $\mathrm{BW})$, the remainders were collected and weighed daily.

The forage mass was determined by the direct visual estimation method with double sampling (Gardner, 1986), performed in a ten-day interval. The canopy height, considered as the distance from the ground to the height of folding leaves $(\mathrm{cm})$, was measured in the same occasions with a ruler, with 20 readings in each experimental unit. In the collected samples, we determined the partial DM of the forage and its botanical and structural composition by manual separation of the components: leaf and stems, inflorescence, dead material and other species. This material was dried at $55^{\circ} \mathrm{C}$ for 72 hours and then weighed to calculate the percentage and mass of each component as well as the leaf:stem ratio.

The forage growth rate $(\mathrm{kg} /$ ha.day of $\mathrm{DM})$ was evaluated by using three exclusion cages located in each paddock. The daily forage availability was obtained by the sum of forage accumulation and forage mass divided by the number of days of the period. The total production of dry matter in the experimental period was calculated as the sum of forage accumulation of each period plus the initial forage mass.

Animals were weighed on January 10th; February 2nd and 23rd; March 16th; and April 13th, with a 12-hour fasting of solids and liquids. On the same dates, body condition score (BCS) was rated, ranging from one (very slim) to five (very fat) according the adapted methodology of Lowman et al. (1973). The stocking rate was calculated by the sum of the average weight of test animals plus the average weight of each put-and-take animal multiplied by the number of days it remained on the paddock, divided by the total number of days of the period. The number of heifers per hectare was determined as the ratio between the stocking rate and the average weight of animals, $300 \mathrm{~kg}$.

Forage availability, expressed in $\mathrm{kg}$ of DM/100 kg BW, was calculated as the ratio between the daily availability of $\mathrm{DM}$ and stocking rate $(\mathrm{kg} / \mathrm{ha} \mathrm{BW})$. The leaf blade availability was determined by multiplying the forage availability by the average percentage of leaf blades in forage mass.

The vertical structure of the pastures was evaluated in three representative areas of the forage mass in each experimental unit and sampling was carried out using $0.25 \mathrm{~m}^{2}$ squares. In each square the forage was cut considering three strata, each $10 \mathrm{~cm}$, from the top to the bottom of the sward. Samples were taken per strata, which were separated manually into stem, leaf blade and dead material components. Then the components were oven-dried (at $65{ }^{\circ} \mathrm{C}$ for 72 hours) and weighed to calculate the bulk density of each component, expressed in $\mathrm{g} / \mathrm{cm}^{3}$.

Forage intake was evaluated during vegetative (February 3rd - 14th) and flowering (March 17th - 28th) periods. Chromium oxide ( $10 \mathrm{~g})$ was dosed daily, at $08 \mathrm{~h} 00$, during a 12-day period (eight days for adaptation and four days for fecal collection). Chromium levels in dried feces were determined by atomic absorption spectrophotometry 
technique adapted by Kozloski et al. (1998). To estimate fecal output, we used the formula: $\mathrm{PF}=$ chromium administered (g/day)/chromium in feces (g/kg DM) (Pond et al., 1989). Forage intake (FI, kg/day of DM) was determined by the formula: $F I=$ fecal production/1- digestibility. Forage intake was also expressed as a percentage of the body weight. The in vitro dry matter digestibility was determined by the technique described by Tilley \& Terry (1963).

From the hand-plucked samples of forage (Euclides et al., 1992), the nitrogen content was determined, according to the AOAC (1984). The neutral detergent fiber (NDF) content was determined according to Robertson \& Van Soest (1981), modified by Komarek (1993). From the percentage of NDF and FI, the NDF intake in \% of body weight was calculated.

Ingestive behavior was assessed by 24 hours of visual observation of test animals on February 18th (vegetative) and March 31th (flowering). The activities of grazing, ruminating or idling were recorded at a ten-minute interval (Jamieson \& Hodgson, 1979) and expressed as total time per day (min/day). Bite rate (bites/minute) was evaluated during day time, when heifers were in grazing activity, at every 10 minutes, by measuring the time taken by animals to perform twenty bites (Hodgson, 1982). The daily number of bites (bites/day) was obtained by multiplying the bite rate by the daily grazing time (minutes/day).

The bite mass (g/bite DM) was estimated by the adapted equation of Allden \& Whittaker (1970): $\mathrm{BM}=\mathrm{I} /(\mathrm{GT} \times \mathrm{BR})$, where: $\mathrm{BM}=$ bite mass $(\mathrm{g} \mathrm{DM}) ; \mathrm{I}=\mathrm{DM}$ intake (g/day) $\mathrm{BR}=$ bite rate (bite/min), GT = grazing time ( $\mathrm{min} /$ day).

The displacement patterns of beef heifers were observed in five cycles of 10 feeding stations. Feeding station is defined as the area available in a half-cylinder shape in front of and on each side of the animal when its front feet are stationary (Ruyle \& Dwyer, 1985), while the footstep was defined as each movement of the forelegs. From these observations, the number of steps between feeding stations and displacement rate (number of steps per minute) were calculated. The daily number of feeding stations was obtained by multiplying the grazing time by the number of feeding stations visited per minute. The amount of bites in each feeding station was calculated as the ratio between the total number of bites per day and number of feeding stations visited per day.

A completely randomized design in a $3 \times 2$ factorial arrangement (three pasture systems and two phenological stages) was used with two area replications for each pasture system. For variables related to ingestive behavior, the animals were considered replicates. The analyses were made according the following general mathematical model: $\gamma_{\mathrm{ijk}}=\mu+\tau_{\mathrm{i}}+\alpha_{\mathrm{j}}+(\tau \alpha)_{\mathrm{ij}}+\lambda_{\mathrm{k}}\left(\tau_{\mathrm{i}}\right)+\varepsilon_{\mathrm{ijk}}$. By the model, $\gamma_{\mathrm{ijk}}=$ dependent variables; $\mu=$ mean of all observations; $\tau_{i}=$ effect of the i-th pasture system; $\lambda_{k}\left(\tau_{i}\right)=$ effect of k-th replication within the $i$-th pasture system (error a); $\alpha_{j}=$ effect of the $\mathrm{j}$-th phenological stage; $(\tau \alpha)_{\mathrm{ij}}=$ interaction between the $\mathrm{i}$-th pasture system and $\mathrm{j}$-th phenological stage; $\varepsilon_{\mathrm{ijk}}=$ random residual error (error b). Normality test of Shapiro-Wilk was performed and non-normal variables such as densities of structural components were transformed by square root. The data were subjected to analysis of variance ( $F$ test), and when significant at 5\%, Tukey test was performed at the same significance level. When interaction was significant, the analyses were made by phenological stage. When differences between treatments were not detected, test of contrasts between Coastcross and Alexandergrass plus AG+SUP were conducted. When the variables were of interest, correlation analyses were performed. The analyses were performed using the statistical package SAS (Statistical Analysis System, version 9.1.3).

\section{Results and Discussion}

Meteorological data for the trial period (Table 1) showed that the rainfall in February and April was below normal rainfall history. The rainfall in January was 2.8 times higher than the average, while in March there was a water deficit $(16.5 \%$ of the total rainfall expected for the period). Average temperatures on the dates of evaluation of ingestive behavior were $24.7^{\circ} \mathrm{C}$ (February 18th) and $21.2^{\circ} \mathrm{C}$ (March 31st).

There was no pasture system $\times$ phenological stage interaction $(\mathrm{P}>0.05)$ for forage mass, forage availability, canopy height, forage growth rate, leaf:stem ratio and leaf blade availability. The forage mass and forage availability did not differ between pasture systems and phenological stages $(\mathrm{P}>0.05)$ with mean values of $3,337 \pm 471 \mathrm{~kg} / \mathrm{ha}$ of dry matter $(\mathrm{DM})$ and $10.7 \pm 1.5 \mathrm{~kg}$ of $\mathrm{DM} / 100 \mathrm{~kg}$ of body weight (BW), respectively. Considering the estimated forage

Table 1 - Average monthly rainfall and temperature during the experimental period and normal history data, Santa Maria/RS

\begin{tabular}{lcccc}
\hline \multirow{2}{*}{ Means } & \multicolumn{4}{c}{ Months } \\
\cline { 2 - 5 } & January & February & March & April \\
\hline Observed & 405.9 & 124.7 & 25.1 & 116.8 \\
Rainfall $(\mathrm{mm})$ & 25.3 & 26.8 & 20.1 & 22.9 \\
Average temperature $\left({ }^{\circ} \mathrm{C}\right)$ & & & & \\
History & 145.1 & 130.2 & 151.7 & 134.7 \\
Rainfall $(\mathrm{mm})^{1}$ & 24.6 & 24.0 & 22.2 & 18.8 \\
Average temperature $\left({ }^{\circ} \mathrm{C}\right)^{1}$ & & & & \\
\hline
\end{tabular}

${ }^{1}$ From 1961 to 2010 (Meteorological Station of Universidade Federal de Santa Maria). 
intake of $2.3 \%$ of BW (NRC, 1996) for this category, there was no limitation to intake, since the forage availability in tropical pastures should be four times higher than the estimated intake (Hodgson, 1982).

Canopy height, forage growth rate, leaf:stem ratio and leaf blade availability were similar between pasture systems $(\mathrm{P}>0.05)$ and different between phenological stages $(\mathrm{P}<0.05)$. A reduction of 24.7 to $16.9 \mathrm{~cm}$ in canopy height was observed from the vegetative to the flowering stage, probably due to the maintenance of the same value of forage mass in both stages and the increase in forage DM content. The same forage mass can take various forms in space, due to several possible combinations of canopy height and pasture bulk density (Carvalho, 1997).

Forage growth rates of the species were, on average, 120 and $40 \mathrm{~kg} \mathrm{DM} / \mathrm{ha}$ in vegetative and flowering stages, respectively. Similar values were observed in Alexandergrass (Costa, 2009) and Coastcross (Carnevalli $\&$ Silva, 1999). The low value for the flowering stage was mainly due to the shortage of rain $(\mathrm{r}=0.85 ; \mathrm{P}=0.0004)$. The total dry matter production for the entire pasture utilization period was $11.3 \pm 1.9,11.8 \pm 0.5$ and $11.3 \pm 0.5 \mathrm{t} / \mathrm{ha} \mathrm{DM}$ for Coastcross, Alexandergrass and AG+SUP, respectively.

The leaf:stem ratio in vegetative and flowering stages was 0.42 and 0.26 , respectively. Values observed in vegetative stage are similar to those observed in Urochloa brizantha Marandu, which resulted in steers gaining around one kilogram per day (Ítavo et al., 2008).

There was a $50 \%$ decrease in the leaf blade availability from the vegetative to the flowering stage. In the vegetative stage the leaf blade availability of $2.5 \%$ was greater than the suggested value for this animal category, considering an estimated forage intake (NRC, 1996). Given that it is desirable to maintain a greater value of leaf blade availability during all period of pasture utilization, as a perennial species, Coastcross has advantage over Alexandergrass, an annual species, because of the constant emissions of new blades. However, this characteristic may be affected if there is water deficit and/or nitrogen limitation (Fernandez et al., 1989).

There was pasture system $\times$ phenological stage interaction for leaf blade bulk density in the $10-20 \mathrm{~cm}$ stratum and for dead material bulk density in the $0-10 \mathrm{~cm}$ stratum $(\mathrm{P}<0.05)$. For other strata, bulk density of leaf blade, dead material, stem and inflorescences and of other species, there was no interaction between pasture system and phenological stage ( $\mathrm{P}>0.05$; Figure 1$)$.

The leaf blade bulk density in the $10-20 \mathrm{~cm}$ stratum showed the highest values in vegetative stage $(\mathrm{P}<0.05)$, while in Coastcross the same leaf blade bulk density was present in both phenological stages. For planning feeding systems, a perennial species such as Coastcross has the ability to constantly emit new leaf blades, which can be an advantageous characteristic when compared with annual species such as Alexandergrass.

In the stratum of 0-10 cm, Coastcross showed lower leaf blade bulk density and higher bulk density in other species $(\mathrm{P}<0.05)$, while in the $10-20 \mathrm{~cm}$ stratum, stem bulk density and dead material bulk density were higher than Alexandergrass and $\mathrm{AG}+\mathrm{SUP}(\mathrm{P}<0.05)$. At the flowering stage, the leaf blade bulk density and stem bulk density in the stratum of $0-10 \mathrm{~cm}$ were lower and dead material bulk density in the $10-20 \mathrm{~cm}$ stratum was higher $(\mathrm{P}<0.05)$. The smaller leaf blade bulk density and stem bulk density verified in the low stratum may indicate the removal of these components by heifers, which were searching for leaves at the lower stratum of the pasture to maintain their intake rate (Illius, 1997). Meanwhile, the increase in dead material bulk density in this stratum is a result of advancements in the physiological cycle of the grass. According to Carvalho (2001), in each phenological stage, the total dry matter of the plant has different proportions of leaves, stems, inflorescences and dead material in the structure of the pasture. This means that the composition of the plant changes over time.
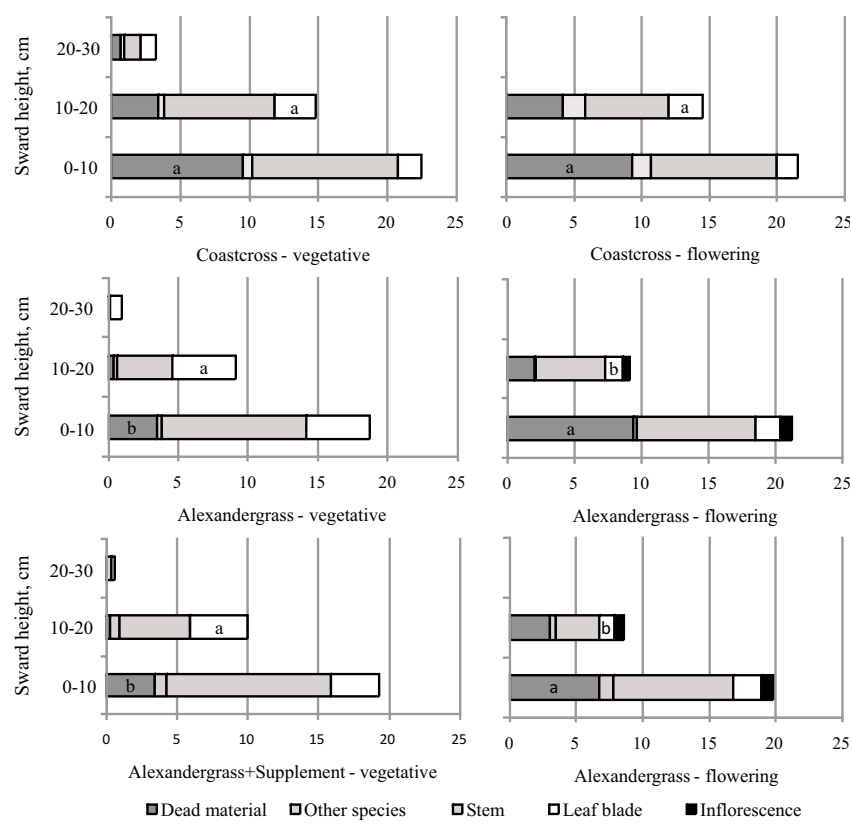

Letters in leaf blade bulk density and dead material bulk density indicate pasture system $\times$ phenological stage interaction $(\mathrm{P}<0.05)$.

Figure 1 - Bulk density $\left(\mathrm{g} / \mathrm{cm}^{3}\right)$ of the canopy structural components in vegetative and flowering phenological stages for Coastcross, Alexandergrass and AG+SUP pasture systems. 
There was pasture system $\times$ phenological stage interaction $(\mathrm{P}=0.0001)$ for crude protein content and no interaction $(\mathrm{P}>0.05)$ for neutral detergent fiber content and in vitro dry matter digestibility (IVDMD). For these two variables, there was difference between pasture systems $(\mathrm{P}<0.01)$ and NDF content differed between phenological stages $(\mathrm{P}<0.01)$.

Crude protein (CP) requirement of heifers (NRC, 1996) was met during the vegetative stage in the three pasture systems. However, at the flowering stage, heifers on AG+SUP consumed forage with the same CP content as those on Alexandergrass and Coastcross, and heifers on Coastcross consumed forage with greater CP content than those in Alexandergrass.

When the supplement was offered at a quantity corresponding to $0.2 \%$ of $\mathrm{BW}$ in $\mathrm{AG}+\mathrm{SUP}$, the heifers actually consumed about $0.12 \%$ and $0.05 \%$ of $\mathrm{BW}$ in vegetative and flowering stages, respectively. These amounts represent an increase of approximately 115 and $53 \mathrm{~g}$ of CP in the diet of each animal during the vegetative and flowering stages, respectively. In AG+SUP system there was a positive correlation $(\mathrm{r}=0.99 ; \mathrm{P}<0.01)$ between the leaf blade availability of Alexandergrass and supplement intake. The reduction of $48 \%$ in leaf blade availability from vegetative to flowering stage was followed by similar reduction in supplement intake. The connection between leaf blade availability with intake of this kind of supplement was also verified by Ítavo et al. (2008), who provided protein supplements to steers grazing on Marandu grass (Urochloa brizantha).
The NDF content of the forage consumed by heifers increased with the passage of phenological stage of grasses $(\mathrm{P}<0.01)$ and the animals on Coastcross consumed pasture with higher NDF content than those in Alexandergrass forage-based systems $(\mathrm{P}<0.01)$. The grass NDF content can be a limiting factor for forage intake in grazing animals caused by physical distension of the rumen-reticulum, a mechanism that becomes evident in tropical pastures with high NDF content (Minson, 1990). The forage consumed in the three pasture systems presented NDF content above the $55-60 \%$ critical threshold (Van Soest, 1994), which may lead to lower degradation of the cell wall and lower passage rate through the gastrointestinal tract of the animal.

There was a pasture system $\times$ phenological stage interaction on idle time, bite rate and bites/day $(\mathrm{P}<0.05)$ and there was no interaction for grazing and rumination time $(\mathrm{P}>0.05)$. Differences between pasture systems for grazing time were observed $(\mathrm{P}<0.01$; Table 3$)$.

The heifers on Coastcross increased grazing time by $18.5 \%$ when compared with the other pasture systems. The main factor that may have contributed was the higher density of stems and dead material in the $20-30 \mathrm{~cm}$ stratum during vegetative and 10-20 $\mathrm{cm}$ in flowering stages, respectively $63 \%$ and $171 \%$ higher than in other pasture systems. The greater presence of these components in the upper stratum for grazing can result in difficulty to reach the leaf blades and ingest forage due to their higher content of NDF and lower IVDMD (Table 2).

The average rumination time was 480.6 minutes, ranging from 346.6 to 577.0 minutes. The lower idle time

Table 2 - Crude protein, neutral detergent fiber and in vitro forage dry matter digestibility in Coastcross, Alexandergrass and AG+SUP pasture systems in vegetative and flowering phenological stages

\begin{tabular}{|c|c|c|c|c|c|c|}
\hline \multirow{2}{*}{ Item } & \multirow{2}{*}{ Pasture system } & \multicolumn{2}{|c|}{ Phenological stage } & \multirow{2}{*}{ Mean } & \multirow{2}{*}{$\mathrm{P}$} & \multirow{2}{*}{ CV $(\%)$} \\
\hline & & Vegetative & Flowering & & & \\
\hline \multicolumn{7}{|c|}{ Crude protein ${ }^{1}$} \\
\hline & Coastcross & $13.5 \mathrm{a}$ & $11.2 \mathrm{a}$ & 12.3 & & \\
\hline & Alexandergrass & $14.0 \mathrm{a}$ & $9.1 \mathrm{~b}$ & 11.6 & 0.0001 & 19.2 \\
\hline & $\mathrm{AG}+\mathrm{SUP}$ & $14.6 \mathrm{a}$ & $9.5 \mathrm{ab}$ & 12.1 & & \\
\hline & Mean & 14.0 & 9.9 & 12.0 & & \\
\hline \multicolumn{7}{|c|}{ Neutral detergent fiber ${ }^{1}$} \\
\hline & Coastcross & 74.8 & 77.9 & $76.3 \mathrm{a}$ & 0.0046 & \\
\hline & Alexandergrass & 68.5 & 74.6 & $71.5 b$ & & 5.4 \\
\hline & AG+SUP & 67.2 & 72.2 & $69.7 b$ & & \\
\hline & Mean & $70.1 \mathrm{~B}$ & 74.9A & & 0.0034 & \\
\hline \multicolumn{7}{|c|}{ In vitro dry matter digestibility ${ }^{1}$} \\
\hline & Coastcross & 44.9 & 51.4 & $48.2 \mathrm{~b}$ & & \\
\hline & Alexandergrass & 61.2 & 57.1 & $59.2 \mathrm{a}$ & 0.0086 & 11.1 \\
\hline & $\mathrm{AG}+\mathrm{SUP}$ & 59.1 & 57.0 & $58.1 \mathrm{a}$ & & \\
\hline & Mean & 55.1 & 55.2 & & & \\
\hline
\end{tabular}


on Coastcross at the flowering stage was a result of the longer time animals spent grazing and ruminating. The correlations between idle time and rumination $(\mathrm{r}=-0.73$; $\mathrm{P}<0.01)$ and grazing time $(\mathrm{r}=-0.59 ; \mathrm{P}<0.01)$ were negative. This result can be attributed to the fact that daily activities of animals are mutually exclusive (Carvalho et al., 2001).

In Alexandergrass and $\mathrm{AG}+\mathrm{SUP}$ pasture systems, the heifers reduced the bite rate at the flowering stage probably because this situation requires more time to manipulate and grasp the forage (Carvalho, 1997) in an environment with lower density of leaf blades (Figure 1). On Coastcross, the animals kept the same bite rate probably because of the same leaf blade bulk density at both stages. There was a high and positive correlation between leaf blade bulk density and bite rate in the $10-20 \mathrm{~cm}$ stratum $(\mathrm{r}=0.88 ; \mathrm{P}=0.0002)$.

The lower leaf blade bulk density observed in the 10-20 cm stratum (Figure 1) in the flowering stage for Alexandergrass and AG+SUP pasture systems may have resulted in the lower daily bites (Table 3 ). This behavioral response can be related to the time spent by animals while they search leaf blades within a feeding station (Roguet et al., 1998b), which is due to the structural composition of the vegetation and its changes - a factor that influences the selection of the diet by herbivores (Illius, 1986).

The variables feeding stations/minute, steps between feeding stations, displacement rate and time per feeding station showed no pasture system $\times$ phenological stage interaction $(\mathrm{P}>0.05)$ and were similar between pasture systems $(\mathrm{P}>0.05)$. There were differences between phenological stages $(\mathrm{P}<0.05)$. At the vegetative stage, heifers visited one more feeding station per minute and spent less time in each feeding station when compared with the flowering stage (Table 4). The permanence of animals per feeding station is linked to the quantity and quality of available forage (Roguet et al., 1998a), which implies that this behavioral pattern is associated with a higher leaf blade bulk density as well as chemical parameters like higher CP and lower NDF content in forage consumed at the vegetative stage.

The lower displacement rates, fewer steps between feeding stations and reduced number of feeding stations visited per day in the flowering stage can be a result of lower leaf blade availability, which made animals walk less in order to explore the feeding stations visited. However, this result may not happen due to the greater diet selectivity and longer time required for selective grazing. The use of contrasts showed that heifers on Coastcross made fewer steps between feeding stations $(\mathrm{P}<0.01)$, had lower displacement rates $(\mathrm{P}<0.10)$ and visited more feeding stations per day $(\mathrm{P}<0.05)$. This result is due to the Coastcross canopy structure, in which leaf blade density is combined with a great density of stems and dead material, causing heifers to visit a greater number of feeding stations per day. According to Prache \& Peyraud (2001), an unfavorable grazing condition motivates the animals to seek another feeding station.

Table 3 - Grazing and idle time, bite rate and bites per day in Coastcross, Alexandergrass and AG+SUP pasture systems in vegetative and flowering phenological stages

\begin{tabular}{|c|c|c|c|c|c|c|}
\hline \multirow{2}{*}{ Item } & \multirow{2}{*}{ Pasture system } & \multicolumn{2}{|c|}{ Phenological stage } & \multirow{2}{*}{ Mean } & \multirow{2}{*}{$\mathrm{P}$} & \multirow{2}{*}{ CV $(\%)$} \\
\hline & & Vegetative & Flowering & & & \\
\hline \multirow[t]{4}{*}{ Grazing time $^{1}$} & Coastcross & 633.3 & 688.0 & $660.6 \mathrm{a}$ & & \\
\hline & Alexandergrass & 568.1 & 576.8 & $572.4 \mathrm{~b}$ & 0.0005 & 10.7 \\
\hline & AG+SUP & 513.3 & 572.0 & $542.6 b$ & & \\
\hline & Mean & 571.6 & 612.3 & & & \\
\hline \multirow[t]{4}{*}{ Idle time ${ }^{1}$} & Coastcross & $418.2 \mathrm{a}$ & $218.5 b$ & 318.3 & & \\
\hline & Alexandergrass & $375.6 a$ & $409.4 a$ & 392.5 & 0.0266 & 24.6 \\
\hline & AG+SUP & $480.2 \mathrm{a}$ & $333.2 \mathrm{a}$ & 406.7 & & \\
\hline & Mean & 424.7 & 320.4 & & & \\
\hline \multirow[t]{4}{*}{ Bite rate ${ }^{2}$} & Coastcross & $40.5 b$ & $37.7 \mathrm{a}$ & 39.1 & & \\
\hline & Alexandergrass & $48.3 \mathrm{a}$ & $29.1 b$ & 38.7 & 0.0002 & 9.8 \\
\hline & AG+SUP & $50.9 \mathrm{a}$ & $32.5 \mathrm{ab}$ & 41.7 & & \\
\hline & Mean & 46.6 & 33.1 & & & \\
\hline \multirow[t]{4}{*}{ Bites/day } & Coastcross & $25636 a$ & $25953 a$ & 25795 & & \\
\hline & Alexandergrass & $27426 a$ & $16661 b$ & 22044 & 0.0025 & 13.7 \\
\hline & AG+SUP & 26161a & $18830 \mathrm{~b}$ & 22496 & & \\
\hline & Mean & 26408 & 20482 & & & \\
\hline
\end{tabular}

$\mathrm{CV}$ - coefficient of variation; AG+SUP - alexandergrass + supplement.

${ }^{1}$ minutes/day.

2 bites/minute.

Means followed by different letters in the column indicate difference by the Tukey test $(\mathrm{P}<0.05)$. 
The number of bites per feeding station showed pasture system $\times$ phenological stage interaction $(P=0.0004)$. Heifers took more bites per feeding station in the Alexandergrass system at the vegetative stage ( 7.2 bites/feeding station), differing only from the animals on Coastcross at the same stage (4.8 bites/feeding station). This difference can be attributed to the presence of other components besides leaf blade in the $20-30 \mathrm{~cm}$ stratum in the Coastcross system (Figure 1), which hinders the bite formation and grasp of leaf blades at each feeding station visited. In the flowering stage, the leaf blade bulk density in the $10-20 \mathrm{~cm}$ stratum is similar for the three pasture systems, which allowed for a similar number of bites per feeding station ( 5.8 bites/ feeding station).

There was no pasture system $\times$ phenological stage interaction for forage and neutral detergent fiber intake $(\mathrm{P}>0.05)$. There were differences between phenological stages and pasture systems for forage intake $(\mathrm{P}<0.05$; Table 5).

The forage intake showed positive correlation with leaf blade availability $(\mathrm{r}=0.82 ; \mathrm{P}<0.001)$. The animals select leaves in the upper stratum of the canopy (Hodgson, 1990), and the lower leaf blade bulk density in the $20-30 \mathrm{~cm}$ stratum (Figure 1) showed higher defoliation at vegetative stage, which made it possible for grazing animals to have a higher forage intake. In the flowering stage, the removal of leaf blades at the lower stratum, not allowing the maintenance of high intake levels, is shown by the lower leaf blade bulk density in the $10-20$ and $0-10 \mathrm{~cm}$ strata. There was positive correlation between forage intake and leaf blade bulk density in the $10-20 \mathrm{~cm}$ stratum $(\mathrm{r}=0.86$; $\mathrm{P}=0.0003$ ). Similar stem bulk density in the $10-20 \mathrm{~cm}$ stratum in both phenological stages (Figure 1) is another factor to be considered, and the presence of stems can be considered a physical limitation to forage intake since the bite depth is reduced (Carvalho, 1997).

Forage intake in $\mathrm{AG}+\mathrm{SUP}$ was higher than in Coastcross $(\mathrm{P}<0.05)$ and showed no difference from Alexandergrass. This result agrees with the statement that, upon receiving protein supplements, animals can increase performance because of several factors, increase in forage intake being the main one (McCollum III \& Horn, 1989). The extra nitrogen supplied to ruminal microorganisms increases protein synthesis and degradation rate, and a greater flow of protein improves the efficiency of energy use in the tissue (Forbes, 2007).

The forage structure and composition changes also modified animal behavior mechanisms and decreased forage intake. Forage intake was positively correlated with the displacement rate $(\mathrm{r}=0.78 ; \mathrm{P}=0.002)$, indicating that a higher number of steps per minute might have an impact on intake; in this case, the compensation for the increased distance between patches by an increase in intake per patch (Demment \& Laca, 1993). This intake was negatively

Table 4 - Feeding station/minute, steps between feeding stations, displacement rate, time/feeding station and feeding stations/day in Coastcross, Alexandergrass and AG+SUP pasture systems in vegetative and flowering phenological stages

\begin{tabular}{|c|c|c|c|c|c|}
\hline \multirow{2}{*}{ Item } & \multicolumn{2}{|c|}{ Phenological stage } & \multirow{2}{*}{ Mean } & \multirow{2}{*}{$\mathrm{P}$} & \multirow{2}{*}{$\mathrm{CV}(\%)$} \\
\hline & Vegetative & Flowering & & & \\
\hline Feeding station/minute & 7.2 & 6.2 & 6.67 & 0.0026 & 7.18 \\
\hline Steps between feeding stations & 1.8 & 1.4 & 1.59 & 0.0313 & 8.92 \\
\hline Displacement rate $^{1}$ & 12.2 & 8.6 & 10.40 & 0.0002 & 8.37 \\
\hline Time/feeding station ${ }^{2}$ & 9.3 & 11.3 & 10.26 & 0.0246 & 5.58 \\
\hline Feeding stations/day & 4078 & 3777 & 3927 & 0.0322 & 25.1 \\
\hline
\end{tabular}

$\mathrm{CV}$ - coefficient of variation; AG+SUP - alexandergrass + supplement.

1 in steps/minute.

2 in seconds.

Table 5 - Forage intake by heifers in Coastcross, Alexandergrass and AG+SUP pasture systems in vegetative and flowering phenological stages

\begin{tabular}{|c|c|c|c|c|c|c|}
\hline \multirow{2}{*}{ Item } & \multirow{2}{*}{ Pasture system } & \multicolumn{2}{|c|}{ Phenological stage } & \multirow{2}{*}{ Mean } & \multirow{2}{*}{$\mathrm{P}$} & \multirow{2}{*}{$\mathrm{CV}(\%)$} \\
\hline & & Vegetative & Flowering & & & \\
\hline \multirow[t]{4}{*}{ Forage intake $^{1}$} & Coastcross & 2.69 & 1.88 & $2.28 \mathrm{~b}$ & & \\
\hline & Alexandergrass & 2.93 & 1.83 & $2.38 \mathrm{ab}$ & 0.0471 & 8.2 \\
\hline & $\mathrm{AG}+\mathrm{SUP}$ & 2.84 & 2.05 & $2.44 \mathrm{a}$ & & \\
\hline & Mean & $2.81 \mathrm{~A}$ & $1.92 \mathrm{~B}$ & & 0.0041 & \\
\hline
\end{tabular}

$\mathrm{CV}$ - coefficient of variation; AG+SUP - alexandergrass + supplement.

${ }^{1}$ in $\%$ of body weight.

Means followed by different uppercase letters in the row and lower case in the column indicate difference by the Tukey test $(\mathrm{P}<0.05)$. 
associated with time/feeding station $(\mathrm{r}=0.60 ; \mathrm{P}=0.03)$. Despite the unfavorable characteristics of the pasture in the flowering stage, there was an increase in time/feeding station, which was not enough to promote a higher forage intake. Charnov (1967) points out to the fact that the animal spends time in the same feeding station until the forage amount is reduced and the intake rate becomes low, then it leaves it and searches a new patch with better opportunity to increase intake.

Regardless of pasture system, forage intake levels verified at the vegetative stage are similar to those described by Euclides et al. (2000) for steers grazing on U. decumbens $(2.67 \% \mathrm{BW})$ and U. bryzantha $(2.79 \% \mathrm{BW})$. On Alexandergrass and pearl-millet grass, Costa (2009) observed average forage intake of $2.3 \%$ and $2.6 \%$ of the BW at the vegetative and reproductive stages, respectively.

The NDF intake was, on average, $1.7 \%$ of the BW and decreased $(\mathrm{P}<0.01)$ from the vegetative $(1.98 \% \mathrm{BW})$ to the flowering stage $(1.44 \%$ of $\mathrm{BW})$. The NDF level of grazed forage may be considered limiting to animal performance at both phenological stages. Barbosa et al. (2007) reported an NDF intake at around $1.8 \%$ of the BW, which is also above the limit of $1.2 \%$ of the BW, which is considered a cap value (Mertens, 1994); however this way of quantifying intake, through rumen fill, may not apply to tropical pastures. It is suggested that other factors regarding intake by the animals rather then the mechanism of distension of rumen-reticulum are responsible for intake control (Euclides et al., 2000).

Bite mass showed no pasture system $\times$ phenological stage interaction $(\mathrm{P}>0.05)$. By contrast analysis, the bite mass, $0.32 \mathrm{~g} \mathrm{DM} /$ bite, on Alexandergrass and $\mathrm{AG}+\mathrm{SUP}$ was greater than on Coastcross, $0.26 \mathrm{~g} \mathrm{DM} / \mathrm{bite}(\mathrm{P}=0.0099)$ and similar between phenological stages $(\mathrm{P}>0.05)$, with an average value of $0.27 \mathrm{~g} \mathrm{DM} / \mathrm{bite}$. This similarity for both stages is probably because harvesting leaf blades may be difficult in the vegetative stage due to the low bulk density of forage components, while at the flowering stage, an increase of stems and dead material was observed in the 10-20 cm stratum. This becomes more evident in Alexandergrass and $\mathrm{AG}+\mathrm{SUP}$ systems by the reduced bite rate in order to grasp and handle these leaves. The time devoted to these processes may have been responsible for the reduction of forage intake because there was no increase in grazing time. According to Poppi et al. (1987), the forage intake decline is a result of imperfect compensation in terms of grazing time in response to declination in intake rate.

The lower bite mass in Coastcross in relation to other pasture systems can be attributed to the stem bulk density in the $20-30 \mathrm{~cm}$ stratum at the vegetative stage and the higher stem bulk density in the $10-20 \mathrm{~cm}$ stratum at the flowering stage. This may have constituted a barrier to bite depth and formation of a higher bite mass (Carvalho, 1997).

The bite mass value observed on Coastcross was below the $0.3 \mathrm{~g} / \mathrm{bite}$ considered critical by Stobbs (1974). In Alexandergrass and AG+SUP pasture systems the values are similar to those verified by Costa (2009) in Alexandergrass, which was $0.33 \mathrm{~g} \mathrm{OM} / \mathrm{bite}$.

The average daily gain (ADG), stocking rate (SR) and body condition score (BCS) showed no pasture system $x$ phenological stage interaction $(\mathrm{P}>0.05)$. There were differences between phenological stages $(\mathrm{P}<0.05$; Table 6$)$. The higher average daily gain of heifers at the vegetative stage is associated with forage intake during this period $(\mathrm{r}=0.77 ; \mathrm{P}=0.003)$ and the $\mathrm{CP}$ content of forage $(\mathrm{r}=0.69$; $\mathrm{P}=0.01)$ and negatively associated with increased NDF content $(\mathrm{r}=-0.87 ; \mathrm{P}=0.0002)$ and dead material bulk density in the $10-20 \mathrm{~cm}$ stratum $(\mathrm{r}=-0.83 ; \mathrm{P}=0.0008)$. The use of protein supplements for heifers on Alexandergrass pasture did not promote higher ADG, SR or BCS in relation to those exclusively on pasture. The $62 \%$ higher stocking rate at the vegetative stage than at flowering stage was possible because of the higher forage growth observed in this period.

In the beginning of the experiment the heifers presented an average $255.4 \mathrm{~kg} \mathrm{BW}, 56.7 \%$ of the adult projected BW and 2.5 scores of BCS. At the end of the utilization of pasture systems, the heifers averaged $306.7 \mathrm{~kg} \mathrm{BW}$ and 3.3 scores of BCS; these values met the minimum parameters for mating, $67 \%$ of adult weight (NRC, 1996), considering an adult animal of $450 \mathrm{~kg}$, and 3.0 scores of BCS (Rocha et al., 2004).

Table 6 - Average daily gain (ADG) and stocking rate of heifers at vegetative and flowering phenological stages

\begin{tabular}{lccccc}
\hline \multirow{2}{*}{ Item } & \multicolumn{2}{c}{ Phenological stage } & & \multirow{2}{*}{$\mathrm{P}$} & $\mathrm{CV}(\%)$ \\
\cline { 2 - 3 } & Vegetative & Flowering & & \\
\hline $\mathrm{ADG}^{1}$ & 0.734 & 0.232 & & 0.0442 & 32.9 \\
Stocking rate $^{2}$ & 8.6 & 5.3 & & 0.0018 & 29.8 \\
\hline $\mathrm{CV}$ - coefficient of variation. & & & & \\
${ }^{1}$ in kg/day. & & & & \\
${ }^{2}$ Average body weight $=300 \mathrm{~kg}$. & & & &
\end{tabular}

\section{Conclusions}

Beef heifers consume more forage in vegetative than in the flowering stage of grasses due to characteristics of each phenological stage, which modifies the ingestive behavior and promotes changes in performance. The provision of protein supplements for grazing beef heifers increases 
forage intake, without reflections on performance. The utilization of perennial (Coastcross) or annual summer pasture (Alexandergrass) with or without supply of protein supplements promotes similar stocking rate and body development and provides adequate nutrient intake for beef heifers to be mated at 18 months of age.

\section{References}

ALLDEN, W.G.; WHITTAKER, I.A. McD. The determinants of herbage intake by grazing sheep: the interrelationship of factors influencing herbage intake and availability. Australian Journal of Agricultural Research, v.21, n.5, p.755-766, 1970.

ASSOCIATION OF OFFICIAL ANALYTICAL CHEMISTS - AOAC. Official methods of analysis. 14.ed. Washington, 1984.

BARBOSA, F.A.; GRAÇA, D.S.; MAFFEI, W.E. et al. Desempenho e consumo de matéria seca de bovinos sob suplementação protéicoenergética, durante a época de transição água-seca. Arquivo Brasileiro de Medicina Veterinária e Zootecnia, v.59, n.1, p.160-167, 2007.

CARNEVALLI, R.A.; SILVA, S.C. Validação de técnicas experimentais para avaliação de características agronômicas e ecológicas de pastagens de Cynodon dactylon cv Coastcross- 1 . Scientia Agrícola, v.56, n.2, p.489-499, 1999.

CARVALHO, P.C.F. A estrutura da pastagem e o comportamento ingestivo de ruminantes em pastejo. In: SIMPÓSIO SOBRE AVALIAÇÃO DE PASTAGENS COM ANIMAIS, 1997, Maringá. Anais... Maringá: UEM, 1997. p.25-52.

CARVALHO, P.C.F.; RIBEIRO FILHO, H.M.N.; POLI, C.H.C. et al. Importância da estrutura da pastagem na ingestão e seleção da dieta pelo animal em pastejo. In: A produção animal na visão dos brasileiros. In: REUNIÃO ANUAL DA SOCIEDADE BRASILEIRA DE ZOOTECNIA, 38., 2001, Piracicaba. Anais... Piracicaba: SBZ, 2001. v.2, p.853-871.

CHARNOV, E.L. Optimal foraging, the marginal value theorem. Theoretical Population Biology, v.9, p.129-136, 1967.

COSTA, V.G. Comportamento de pastejo e ingestão de forragem por novilhas de corte em pastagens de milheto e papuã. 2009. 69f. Dissertação (Mestrado em Zootecnia) - Universidade Federal de Santa Maria, Santa Maria.

DEMMENT, M.W.; LACA, E.A. The grazing ruminant: models and experimental techniques to relate sward structure and intake. In: WORLD CONFERENCE ON ANIMAL PRODUCTION, 7., 1993, Edmonton. Proceedings... Edmonton, 1993. p.439-460.

EMPRESA BRASILEIRA DE PESQUISA AGROPECUÁRIA EMBRAPA. Centro Nacional e Pesquisa em Solos. Sistema brasileiro de classificação de solos. Brasília: Embrapa-SPI; Rio de Janeiro: Embrapa-Solos, 2006. 306p.

EUCLIDES, V.P.B.; MACEDO, M.C.M.; OLIVEIRA, M.P. Avaliação de diferentes métodos de amostragem sob pastejo. Revista da Sociedade Brasileira de Zootecnia, v.21, n.4, p.691-702, 1992.

EUCLIDES, V.P.B.; CARDOSO, E.G.; MACEDO, M.C.M. et al. Consumo voluntário de Brachiaria decumbens cv. Basilisk e Brachiaria brizantha cv. Marandu sob pastejo. Revista Brasileira de Zootecnia, v.29, n.6, p.2200-2208, 2000.

FERNANDEZ, D.; PARETAS, J.J.; FONSECA, E. Influencia de la fertilizacion com nitrogeno y la frecuencia de corte em bermuda cruzada 1 (Coastcross 1) com riego y sin el. I. Rendimiento y economia. Ciencia y Tecnica em La Agricultura, Pastos e Forajes, v.12, n.1, p.41-55, 1989.

FORBES, J.M. Voluntary food intake and diet selection in farm animals. 2.ed. Oxfordshire: CABI, 2007.

GARDNER, A.L. Técnicas de pesquisa em pastagens e aplicabilidade de resultados em sistemas de produção. Brasília: IICA/Embrapa CNPGL, 1986. 197p. (Série Publicações Miscelâneas, 634).
HODGSON, J. Influence of sward characteristics on diet selection and herbage intake by the grazing animal. In: HACKER, J.B. (Ed.) Nutritional limits to animal production from pastures. 1982, St Lucia. Proceedings... St Lucia, Queensland, 1982. p.153-166.

HODGSON, J. Grazing management: science into practice. England: Longman Scientific \& Technical, 1990. 201p.

ILLIUS, A.W. Foraging behavior and diet selection. In: GUNDMUNDSSON, O. (Ed.) Grazing Research at Northern Latitudes. New York and London: Plenum Press, 1986. p.227-236.

ILLIUS, A.W. Advances and retreats in specifying the constraints of intake in grazing ruminants. In: INTERNATIONAL GRASSLAND CONGRESS, 18., 1997, Winnipeg, Manitoba. Proceedings... Winnipeg, Manitoba, 1997. p.39-44.

ÍTAVO, L.C.V.; TOLENTINO, T.C.P., ÍTAVO, C.C.B.F. et al. Consumo, desempenho e parâmetros econômicos de novilhos Nelore e F1 Brangus-Nelore terminados em pastagens, suplementados com mistura mineral e sal nitrogenado com uréia e amiréia. Arquivo Brasileiro de Medicina Veterinária e Zootecnia, v.60, p.419-427, 2008.

JAMIESON, W.S.; HODGSON, J. The effect of daily herbage allowance and sward characteristics upon the ingestive behavior of calves under strip-grazing management. Grass and Forage Science, v.34, p.261-271, 1979.

KOMAREK, A.R. A fiber bag procedure for improved efficiency of fiber analyses. Journal of Dairy Science, v.76, supl.(1), p.250, 1993.

KOZLOSKI, G.V.; FLORES, E.M.M.; MARTINS, A.F. et al. Use of chromium oxide in digestibility studies: variations of the results as a function of the measurement method. Journal Science Food Agriculture, v.76, p.373-376, 1998.

LE DU, Y.L.P.; PENNING, P.D. Animal based techniques for estimating herbage intake. In: LEAVER, J.D. (Ed.) Herbage intake book. Hurley: British Grassland Society, 1982. p.37-75.

LOWMAN, B.G.; SCOTT, N.; SOMERVILLE, S. Condition scoring beef cattle. Edinburgh: East of Scotland College of Agriculture, 1973. 8p. (Bulletin 6).

MATHIS, C.P.; COCHRAN, R. C.; HELDT, J. S. et al. Effects of supplemental degradable intake protein on utilization of medium-tolow quality forages. Journal of Animal Science, v.78, p.224-232, 2000.

McCOLLUM III; F.T.; HORN, G. W. Protein supplementation of grazing ruminants. Journal of Animal Science, v.67, p.304-311, 1989.

MERTENS, D.R. Regulation of forage intake. In: FAHEY JR., G.C. (Ed.). Forage quality evaluation and utilization. Madison: American Society of Agronomy; Crop Science of America; Soil Science of America, 1994. p.450-493.

MINSON, D.L. Forage in ruminant nutrition. San Diego: Academic Press, 1990. 483p.

MOORE, J.E. Forage quality indices: Development and applications. In: FAHEY JR., G.C. (Ed.). Forage quality, evaluation and utilization. Madison: American Society of Agronomy; Crop Science of America; Soil Science of America, 1994. p.967-998.

MORAES, A.; CARVALHO, P.C.F.; Comportamento ingestivo de ruminantes: bases para o manejo sustentável do pasto. In: CECATO, U.; JOBIM, C.C. (Org.). Manejo sustentável em pastagem. Maringá: UEM, 2005. v.1, p.1-20.

NATIONAL RESEARCH COUNCIL - NRC. Nutrient requirement of beef cattle. 7.ed. Washington: National Academy, 1996. 90p.

POPPI, D.P.; HUGHES, T.P.; L'HUILLIER, P.J. Intake of pasture by grazing ruminants. In: NICOL, A.M. (Ed.) Livestock feeding at pasture. Hamilton: New Zealand Society of Animal Production, 1987. p.55-64. (Occasional publication, 10).

PRACHE, S.; PEYRAUD, J. Foraging: behavior and intake in temperate cultivated grassland. In: INTERNATIONAL GRASSLAND CONGRESS, 19., 2001, São Pedro. Proceedings... São Pedro: 2001. p.309-319.

POND, K.R.; ELLIS, W.C.; MATIS, J.H. et al. Passage of chromiummordanted and rare earth-labeled fiber: time of dosing kinetics. Journal of Animal Science, v.67, n.4, p.1020-1028, 1989. 
RESTLE, J.; ROSO, C.; AITA, V. et al. Produção animal em pastagem com gramíneas de estação quente. Revista Brasileira de Zootecnia, v.31, n.3, p.1491-1500, 2002 (supl.).

ROCHA, M.G.; PILAU, A.; SANTOS, D.T. et al. Desenvolvimento de novilhas de corte submetidas a diferentes sistemas alimentares. Revista Brasileira de Zootecnia, v.33, n.6, p.2123-2131, 2004.

ROCHA, M.G.; PEREIRA, L.E.; SCARAVELLI, L.F. et al. Produção e qualidade de forragem da mistura de aveia e azevém sob dois métodos de estabelecimento. Revista Brasileira de Zootecnia, v.36, n.1, p.7-17, 2007.

ROBERTSON, J.B.; VAN SOEST, P.J. The detergent system of analysis. In: JAMES, W.P.T.; THEANDER, O. (Eds.) The analysis of dietary fibre in food. New York: Marcel Dkker, 1981. Chapter 9, p.123-158.

ROGUET, C.; PRACHE, S.; PETIT, M. Feeding station behavior of ewes in response to forage availability and sward phenological stage. Applied Animal Behavior Science, v.56, p.187-201, 1998a.

ROGUET, C.; DUMONT, B.; PRACHE, S. Selection and use of feeding sites and feeding stations by herbivores. A review. Annales de Zootechnie, v.47, n.4, p.225-244, 1998 b.

RUYLE, G.B.; DWYER, D.D. Feeding stations of sheep as an indicator of diminished forage supply. Journal of Animal Science, v.51, n.2, p.349-353, 1985.

STOBBS, T.H. Rate of biting by Jersey cows as influenced by yield and maturity of tropical grasses. Tropical Grasslands, v.25, n.8, p.81-87, 1974 .

TILLEY, J.M.A.; TERRY, R.A. A two-stage technique of the "in vitro" digestion of forage crop. Journal British Grassland Society, v.18, n.2, p.104-111, 1963.

VAN SOEST, P.J. Nutritional ecology of the ruminant. 2.ed. Ithaca: Cornell University, 1994. 476p. 